\title{
EFFECT OF LOCAL HEATING ON BLOOD FLOW AND METABOLISM IN THE TESTIS OF THE CONSCIOUS RAM
}

\author{
G. M. H. WAITES AND B. P. SETCHELL \\ C.S.I.R.O., Division of Animal Physiology, The Ian Clunies Ross \\ Animal Research Laboratory, Prospect, N.S.W., Australia
}

(Received 21st April 1964)

\begin{abstract}
Summary. The metabolic effects of elevated temperature on the testes of conscious rams have been investigated. Locally heating the testes above $39^{\circ} \mathrm{C}$ for 2 to $2 \frac{1}{2} \mathrm{hr}$ caused moderate or severe seminal degeneration. Blood flow through the testes was not consistently changed by the heating applied. More oxygen was removed from a unit volume of the blood passing through the testes when testicular temperatures were higher than 36.3 to $37.2^{\circ} \mathrm{C}$, than at control temperatures. The oxygen content of the blood in the spermatic veins fell to $2 \cdot 7$ to $4.9 \mathrm{ml} 0_{2} / 100 \mathrm{ml}$ during heating, and oxygen uptake by the testis and epididymis increased by about $70 \%$. In most testes glucose uptake was increased by heating; there was no consistent change in lactate production.

It was concluded that heat sufficient to cause spermatogenic damage results in hypoxia in the testis but does not consistently alter the blood flow or the supply of glucose or the important role of glucose in testicular metabolism.
\end{abstract}

\section{INTRODUCTION}

Many studies have reported the changes which occur in semen quality following periods of elevated testicular temperature. Few have attempted to explain in metabolic terms how heat brings about its effect on spermatogenesis. This is because the in vivo metabolic requirements of the testis at its normal temperature are incompletely understood, as techniques for this type of study have not been available. Apart from the measurement of blood flow and oxygen consumption in the testes of decerebrate dogs after laparotomy (Himwich \& Nahum, 1929), what is known has been derived from manometric studies on testicular tissue (Dickens \& Greville, 1933; Elliott, Greig \& Benoy, 1937) and the in vitro metabolism of normal and cryptorchid testes has been compared (Tepperman, Tepperman \& Dick, 1949). More recently, VanDemark \& Ewing (1963) used a simple perfusion procedure in conjunction with in vitro studies to examine the effects of temperature on the metabolic activity of isolated rabbit's testes (Ewing \& VanDemark, 1963a, b).

By implanting catheters into blood vessels and measuring blood flow and arterio-venous differences simultaneously, Setchell \& Waites (1964) were able 
to demonstrate the importance of carbohydrate in the testicular and epididymal metabolism of conscious rams. The same techniques have been used in the present study to determine whether testicular metabolic rate, or the role of carbohydrate in testicular metabolism, changed during the local application of heat that was sufficient to cause disruption of spermatogenesis.

\section{MATERIALS AND METHODS}

ANIMALS

Six Merino rams, aged 5 to 6 years and weighing 48 to $66 \mathrm{~kg}$, were used. They ate $1000 \mathrm{~g}$ of lucerne chaff and oats and $2 \mathrm{~g}$ of ferrous sulphate daily and received injections of vitamins A and D (500,000 i.u. of each) every 3 months. They each stood in a metabolism cage in an air-conditioned room, the temperature of which never exceeded $25^{\circ} \mathrm{C}$.

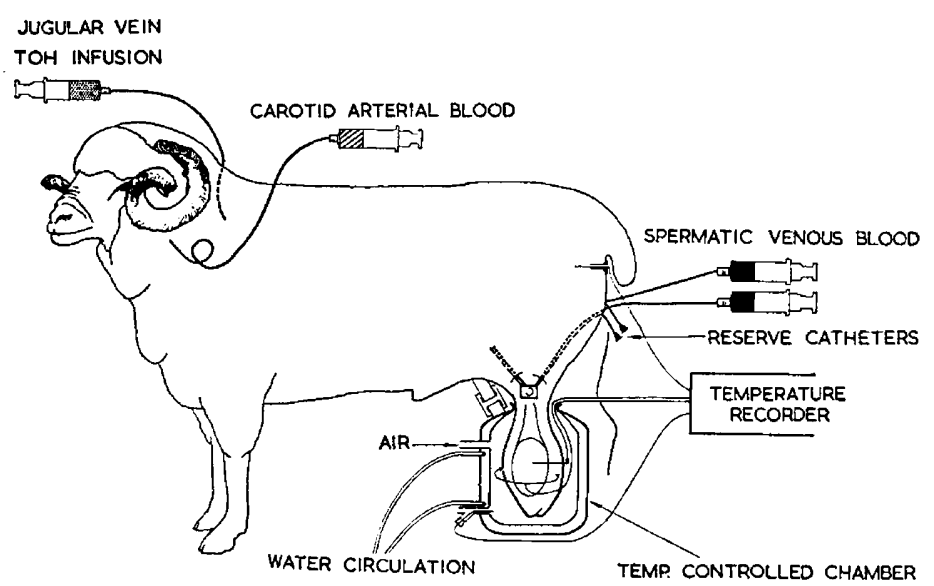

TEXT-FIG. 1. Diagram to show the position of the vascular catheters and the apparatus for locally heating the testes of conscious rams. TOH, tritiated water.

SEMEN EVALUATION

Semen was collected from all the rams by means of an artificial vagina at 3 to 4 day intervals. The rams ejaculated in a set order but with a different ram first at each collection. The semen was evaluated by the methods described by Moule \& Waites (1963). At least ten samples were collected from each ram before heating.

\section{CATHETER INSERTION}

Food and water were withheld from each ram for 1 day before the operations. Anaesthesia was induced with an intravenous dose of pentobarbitone sodium B.P. (17 to $21 \mathrm{mg} / \mathrm{kg}$ ) and maintained with halothane ('Fluothane', I.C.I.) administered in oxygen in a closed circuit through an endotracheal tube. Under aseptic conditions the internal spermatic veins on both sides were exposed through incisions in the anterior skin of the scrotum and two polyvinylchloride (P.v.C.) catheters $(0.56 \mathrm{~mm}$ I.D., $1.16 \mathrm{~mm}$ O.D.) with two side-holes and filled with heparin-saline $(10 \mathrm{mg} / \mathrm{ml} 0.9 \%)$ were inserted centrally for $12 \mathrm{~cm}$ on each side (see Setchell \& Waites, 1964). They were then sealed into P.v.c. tubes of larger 
bore which were brought subcutaneously lateral to the anus and then through a stab-wound in the skin (Text-fig. 1). Later, samples were withdrawn from one, and the other was kept in reserve. A similar P.v.c. catheter was inserted into the left carotid artery and a polyethylene catheter $(1.5 \mathrm{~mm}$ o.D.) into the right jugular vein. The rams recovered, supported in a standing position by a canvas stretcher in their metabolism cage, and were able to stand unaided within 90 min of stopping anaesthesia.

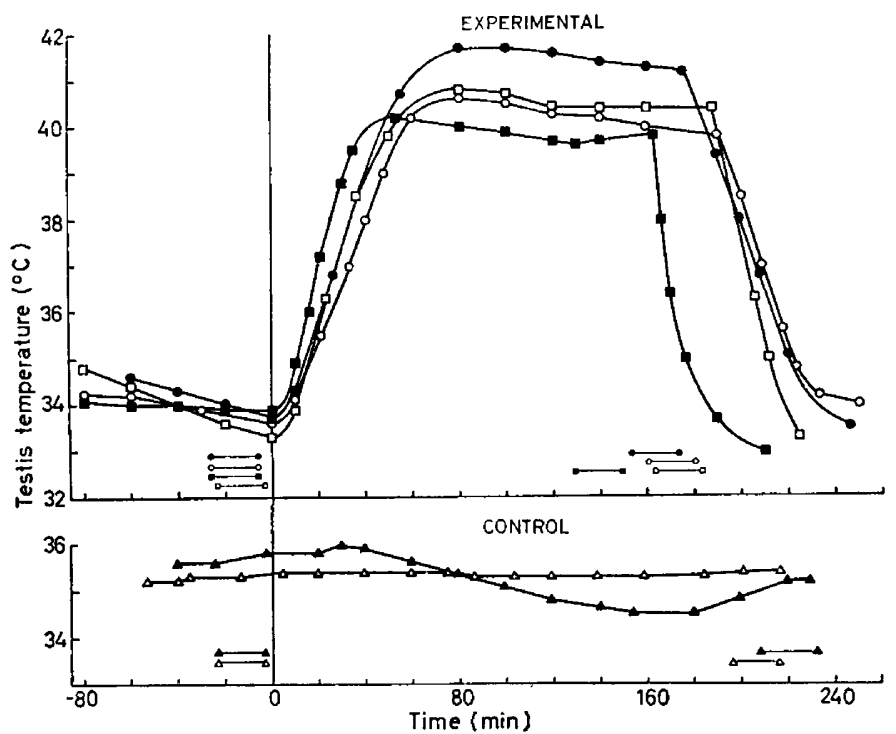

TExT-Fig. 2. The testicular temperatures of the experimental and control rams and the time when blood flow estimations were made. $, 0, \square, \square:$ Rams 1 to 4 respectively; $\Delta, \Delta$ : control rams 5 and 6 . Heating started at time 0 min; $-0,0-0$, etc.: periods when blood-flow was estimated.

\section{EXPERIMENT}

About $20 \mathrm{hr}$ after the insertion of the catheters a needle-thermocouple was thrust deep into the left testis, spring-loaded bare thermojunctions were applied to the anterior and posterior surfaces of the scrotum, and a thermocouple was inserted into the rectum. The scrotum was put into an insulated chamber through which air at any required temperature could be circulated; the temperature of the wall of the chamber was also controlled (Text-fig. 1; see also Waites \& Voglmayr, 1963). The temperature of the air leaving the chamber was registered by a thermocouple; all temperatures were recorded automatically at least once a minute as previously described (Waites \& Moule, 1961). The air in the chamber and the water in its wall were circulated at 18 to $20^{\circ} \mathrm{C}$ during an initial control period of 60 to $80 \mathrm{~min}$.

Respiratory rate was recorded and during the last $30 \mathrm{~min}$ blood flow through both testes and epididymides was estimated by means of an infusion of tritiated water (Setchell \& Waites, 1964). This entailed the removal of ten successive blood samples (each $6 \mathrm{ml}$ ) in $20 \mathrm{~min}$ from the carotid artery and from right and left spermatic veins. The temperatures of the water in the chamber jacket and of the circulating air were then quickly raised to 42 to $44^{\circ} \mathrm{C}$ and the air was 
not dried so that its humidity rose. After scrotal and testicular temperatures had risen above $39^{\circ} \mathrm{C}$, conditions were adjusted to maintain testicular temperatures steady for 130 to $160 \mathrm{~min}$. The blood flow was again measured using tritiated water during the last $30 \mathrm{~min}$ of this time (Text-fig. 2). The temperature of the circulating water and air was then lowered and the testicular temperature observed until it fell to within $0.5^{\circ} \mathrm{C}$ of the pre-heating temperature. Blood samples were removed simultaneously from the carotid artery and both spermatic veins for the estimation of oxygen content during the warming-up and cooling-down periods in three rams.

The chamber was removed, all catheters were gently pulled out, and any bleeding staunched by gentle pressure. Four rams were heated in this way; a further two rams were controls and treated in the same way in all respects except that no heating chamber was applied. Food and water were withheld until the following morning, i.e. $64 \mathrm{hr}$ after the previous meal, in case the act of feeding would start bleeding from the carotid artery.

Semen collections were resumed 4 to 7 days after the experiment.

\section{ANALYTICAL METHODS}

The blood samples (ten arterial, twenty spermatic venous) removed during each blood flow estimation were used to measure the arterio-venous (A-v) differences across the testes and epididymides of oxygen (as already described, Setchell \& Waites, 1964) and of glucose and lactate. Plasma was deproteinized by mixing with an equal volume of $0.6 \mathrm{~N}$ perchloric acid, glucose was determined in the protein-free supernatant by the method of Huggett \& Nixon (1957) and lactate by the method of Lundholm, Mohme-Lundholm \& Vamos (1963).

Tritium was estimated in all plasma samples to give one estimation of testicular and epididymal blood flow for the $20 \mathrm{~min}$ sampling period as described (Setchell \& Waites, 1964), except that $8 \mathrm{ml}$ of toluene-scintillator reagent and $2 \mathrm{ml}$ absolute ethanol were used instead of $5 \mathrm{ml}$ and $4 \mathrm{ml}$ respectively.

\section{RESULTS}

TESTICULAR TEMPERATURE AND CHANGES IN SEMINAL CHARACTERS

The temperature deep within the left testes of the experimental rams was in the range 33.3 to $34.8^{\circ} \mathrm{C}$ during the control period. It was raised above $39^{\circ} \mathrm{C}$ in 30 to $50 \mathrm{~min}$ and maintained above this temperature for 133 to $157 \mathrm{~min}$ with maximum temperatures of $41 \cdot 7,40 \cdot 6,40 \cdot 2$ and $40 \cdot 8^{\circ} \mathrm{C}$ in Rams 1 to 4 respectively (Text-fig. 2). Testicular temperatures of the control rams were kept below $36 \cdot 0^{\circ} \mathrm{C}$ throughout.

The only sign of testicular damage in the control rams was the intermittent appearance of small numbers of multi-nucleated 'giant' cells in the semen collected from one ram during Days 20 to 45 ; all other seminal characters examined were unaffected by the experimental procedures.

All experimental rams produced semen exhibiting varying degrees of damage following treatment. Increased numbers of dead and tailless spermatozoa were first observed on Days 11 and 13 after heating in Rams 1 and 2 and on Day 18 in Rams 3 and 4. The semen of Ram 1, which was the most severely heat- 
treated, contained 85 to $100 \%$ dead spermatozoa between Days 15 to 39 ; the number of spermatozoa in its ejaculates declined from Day 11 until almost none were present on Day 42 ; recovery was rapid and the semen was again normal on Day 53. The semen of Rams 2 to 4 contained 5 to $50 \%$ tailless and up to $70 \%$ dead spermatozoa between Days 13 to 41 (Ram 2) and Days 18 to 43 (Rams 3 and 4). The number of spermatozoa in two successive ejaculates collected on Days 39 and 43 from Rams 2 and 4 was low, but rose to normal again in succeeding samples. Giant cells were present in all samples collected from Ram 1 and intermittently in the semen of the other rams between Days 15 to 67, but in greater numbers and more frequently than in the one control ram in which they appeared.

TABLE 1

BLOOD FLOW THROUGH THE TESTIS AND EPIDIDYMIS OF CONSGIOUS RAMS BEFORE AND DURING LOCAL HEATING, AND ESTIMATES IN CONTROL RAMS

\begin{tabular}{|c|c|c|c|c|}
\hline \multirow{2}{*}{ Ram } & \multirow{2}{*}{ Testis } & \multicolumn{3}{|c|}{ Blood flow $(\mathrm{ml} / 100 \mathrm{~g} / \mathrm{min})$} \\
\hline & & Before heating* & During heating* & Change (\%) \\
\hline $\begin{array}{c}\text { EXPERI- } \\
\text { MENTAL } \\
1\end{array}$ & $\begin{array}{l}\text { Lt. } \\
\text { Rt. }\end{array}$ & $\begin{array}{l}9 \cdot 5 \\
9 \cdot 5\end{array}$ & $\begin{array}{l}12 \cdot 5 \\
12.5\end{array}$ & $\begin{array}{l}+32 \\
+32\end{array}$ \\
\hline 2 & $\begin{array}{l}\text { Lt. } \\
\text { Rt. }\end{array}$ & $\begin{array}{l}9 \cdot 0 \\
9 \cdot 8\end{array}$ & $\begin{array}{l}9 \cdot 2 \\
8 \cdot 3\end{array}$ & $\begin{array}{l}+2 \\
-15\end{array}$ \\
\hline 3 & $\begin{array}{l}\text { Lt. } \\
\text { Rt. }\end{array}$ & $\begin{array}{l}12.0 \\
10.7\end{array}$ & $\begin{array}{l}12.5 \\
11 \cdot 1\end{array}$ & $\begin{array}{l}+4 \\
+4\end{array}$ \\
\hline 4 & $\begin{array}{l}\text { Lt. } \\
\text { Rt. }\end{array}$ & $\begin{array}{r}10 \cdot 3 \\
9 \cdot 2\end{array}$ & $\begin{array}{l}9 \cdot 2 \\
8 \cdot 6\end{array}$ & $\begin{array}{r}-10 \\
-5\end{array}$ \\
\hline \multicolumn{2}{|l|}{ Mean \pm S.E.M. } & $10 \cdot 0 \pm 0 \cdot 3$ & $10 \cdot 5 \pm 0 \cdot 7$ & \\
\hline $\begin{array}{c}\text { Controls } \\
\overline{\mathbf{j}}\end{array}$ & $\begin{array}{l}\text { Lt. } \\
\text { Rt. }\end{array}$ & $\begin{array}{l}12 \cdot 4 \\
10 \cdot 1\end{array}$ & $\begin{array}{l}11.5 \\
11 \cdot 1\end{array}$ & $\begin{array}{r}-7 \\
+10\end{array}$ \\
\hline 6 & $\begin{array}{l}\text { Lt. } \\
\text { Rt. }\end{array}$ & $\begin{array}{l}8 \cdot 5 \\
8 \cdot 5\end{array}$ & $\begin{array}{l}8 \cdot 8 \\
8 \cdot 7\end{array}$ & $\begin{array}{l}+3 \\
+2\end{array}$ \\
\hline \multicolumn{2}{|l|}{ Mean \pm S.E.M. } & $9 \cdot 9 \pm 0.9$ & $10 \cdot 0 \pm 0.7$ & \\
\hline
\end{tabular}

* See Text-fig. 2.

BLOOD FLOW

Blood flow through the testis and epididymis was unchanged by heating in three rams but increased from 9.5 to $12.5 \mathrm{ml} / 100 \mathrm{~g} / \mathrm{min}$ in both sides in Ram 1 (Table 1). The estimates of blood flow made on the control rams, 3 to $4 \mathrm{hr}$ apart (Text-fig. 2) did not differ by more than $10 \%$.

\section{OXYGEN UPTAKE AND METABOLIC RATE}

The oxygen content of the arterial blood was unchanged by locally heating the scrotum (Text-fig. 3 ). The differences between the oxygen contents of the arterial and spermatic venous blood during the control period in all rams were 4.3 to $7 \cdot 1 \mathrm{ml} / 100 \mathrm{ml}$ blood. These values when multiplied by the corresponding values for blood flow give the uptake of oxygen by the testis and epididymis; this, 
during the control period, was $13 \cdot 2 \pm 0 \cdot 6 \mu$ moles/g tissue/hr (mean \pm S.E.M.) for the experimental rams and $16 \cdot 2 \pm 0 \cdot 6$ for the control rams (Table 2). This value was unchanged in the control rams by standing for as long as the experimental rams.

The oxygen content of the blood in the spermatic veins dropped sharply when the temperature of the testis had risen from normal values to about $37^{\circ} \mathrm{C}(36 \cdot 3$ to $37 \cdot 2^{\circ} \mathrm{C}$ ) ; very little further fall occurred as the temperature of the testis rose from about $37^{\circ} \mathrm{C}$ to about $40^{\circ} \mathrm{C}$ and spermatic venous blood contained 2.7 to 4.9 vols $\mathrm{O}_{2} / 100 \mathrm{ml}$ (Text-figs. 3 and 4 ). The uptake of oxygen by the testis and epididymis increased by about $70 \%$ over the control to $22.0 \pm 1.7 \mu$ moles $/ \mathrm{g}$ fresh tissue/hr after the testes had been above $39 \cdot 0^{\circ} \mathrm{C}$ for 100 to $144 \mathrm{~min}$. When the testes were cooling down, the oxygen content of the spermatic venous blood remained low while their temperature was above about $37^{\circ} \mathrm{C}\left(36.2\right.$ to $\left.37.0^{\circ} \mathrm{C}\right)$ but when it had dropped to about $34^{\circ} \mathrm{C}\left(33.7\right.$ to $\left.34 \cdot 2^{\circ} \mathrm{C}\right)$ the oxygen in the spermatic venous blood had risen again into the pre-heating range (Text-fig. 4 ).

TABLE 2

EFFECT OF HEATING THE SCROTUM ON THE UPTAKE OF OXYGEN AND GLUCOSE, AND THE PRODUCTION OF LACTATE BY THE TESTES

\begin{tabular}{|c|c|c|c|c|}
\hline & \multicolumn{2}{|c|}{ Experimental (8 testes, 4 rams) } & \multicolumn{2}{|c|}{ Control ( 4 testes, 2 rams) } \\
\hline & Before heating & During heating & Period 1 & Period 2 \\
\hline $\begin{array}{l}\text { Oxygen uptake }(\mu \text { moles } / \mathrm{g} / \mathrm{hr}) \\
\text { Glucose uptake }(\mu \mathrm{moles} / \mathrm{g} / \mathrm{hr}) \\
\text { Lactate production }(\mu \mathrm{moles} / \mathrm{g} / \mathrm{hr})\end{array}$ & $\begin{array}{l}13 \cdot 2 \pm 0 \cdot 6 \\
2 \cdot 15 \pm 0 \cdot 15 \\
0 \cdot 77 \pm 0 \cdot 34\end{array}$ & $\begin{aligned} 22 \cdot 0 & \pm 1 \cdot 7 \\
2 \cdot 58 & \pm 0 \cdot 29 \\
0 \cdot 04 & \pm 0 \cdot 31\end{aligned}$ & $\begin{array}{l}16 \cdot 2 \pm 0 \cdot 6 \\
3 \cdot 11 \pm 0 \cdot 18 \\
0 \cdot 35 \pm 0 \cdot 56\end{array}$ & $\begin{array}{l}16 \cdot 0 \pm 0.5 \\
2 \cdot 38 \pm 0.08 \\
0.44 \pm 0.32\end{array}$ \\
\hline $\begin{array}{l}\text { Percentage of oxygen accountable } \\
\text { by glucose oxidation }\end{array}$ & $97 \pm 4 \cdot 8$ & $74 \pm 10$ & $115 \pm 6 \cdot 6$ & $89 \pm 0 \cdot 6$ \\
\hline
\end{tabular}

Figures given are means \pm S.E.M.

\section{GLUCOSE AND LAGTATE UPTAKE AND METABOLIC RATE}

The concentration of glucose in the arterial plasma was unchanged by locally heating the scrotum in three rams and rose slightly in one; the range of 46 to $86 \mathrm{mg} / 100 \mathrm{ml}$ recorded in all rams is in the normal range (Reid, 1950). The uptake of glucose by the testes and epididymides of three rams increased during local testicular heating by 22 to $85 \%$ (mean $+46 \%$ ) but decreased bilaterally in one (Ram 3; mean $-40 \%)$; the overall change was a $20 \%$ increase (Table 2). The uptake of glucose by the testes and epididymides of the control rams fell from the range of 2.67 to $3.50 \mu$ moles $/ \mathrm{g} / \mathrm{hr}$ to 2.32 to $2.62 \mu \mathrm{moles} / \mathrm{g} / \mathrm{hr}$ (mean $-23 \%$ ) after standing. The percentage of the oxygen removed by the testes and epididymides, which could be accounted for by the oxidation of glucose, decreased on standing in all rams whether the scrotum was heated or not (Table 2).

Most of the testes and epididymides of quietly standing rams produced a small amount of lactate; there was a small uptake of lactate by one testis in each of two rams. There was no constant change after heating the scrotum or in the control rams after standing (Table 2). 
THERMO-REGULATORY RESPONSES

spiratory rates increased from the range 16 to $60 / \mathrm{min}$ to maximum values of ; to $176 / \mathrm{min}$ on heating the scrotum in all experimental rams. The polypnoea tinued throughout the period of testicular heating. Rectal temperatures of experimental rams fell by 1.0 to $1.5^{\circ} \mathrm{C}$ during scrotal heating. Sharp falls

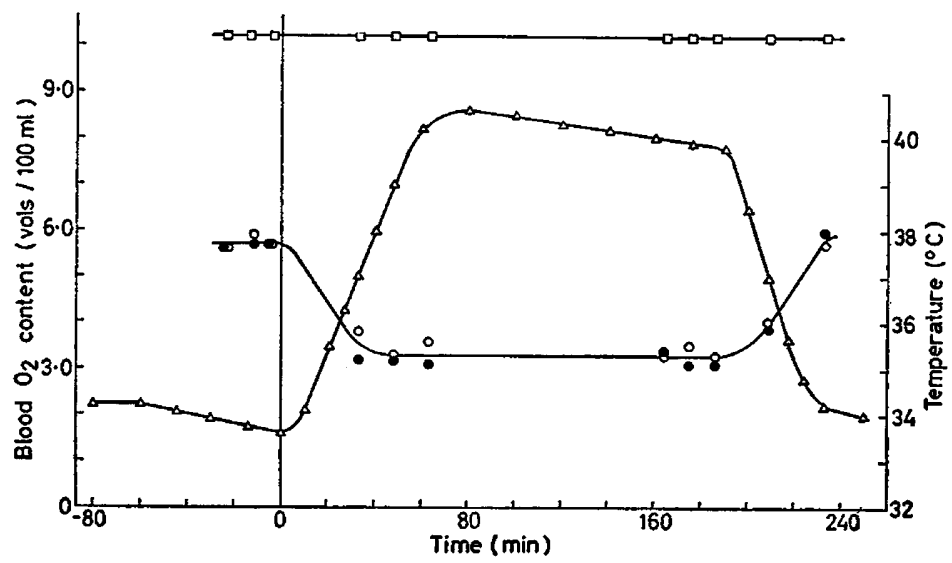

TEXT-FIG. 3. The relationship between the temperature of the testis $(\Delta)$ of Ram 2 and the oxygen content of blood in its carotid artery $(\square)$, and right (O) fand left (O) spermatic veins. 0 min: heating started; 190 min: cooling started.

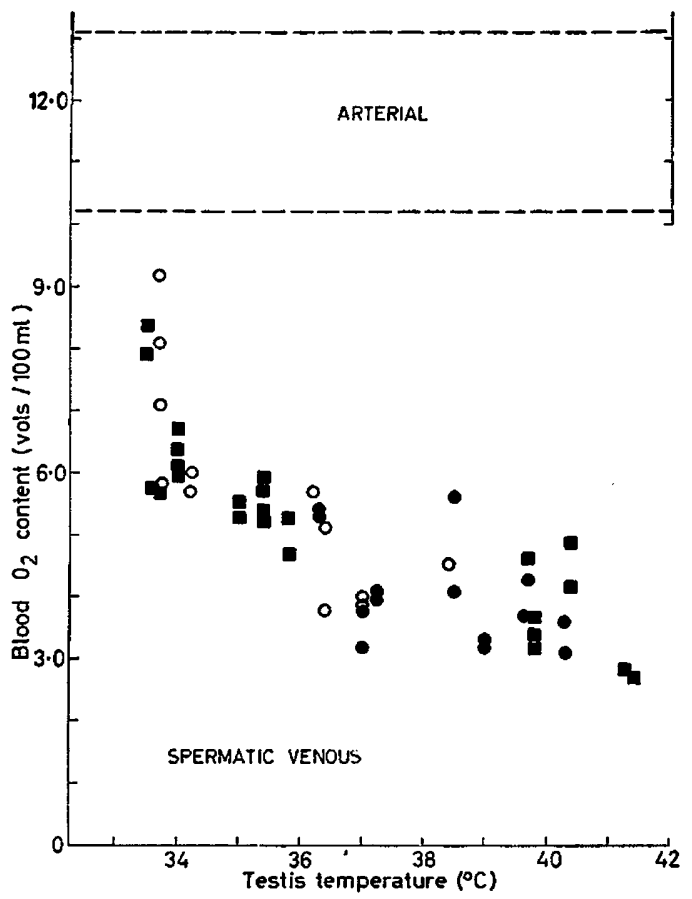

TEXT-FIG. 4. The oxygen content of the venous blood draining the testes at steady ( $\square$ ), rising $(O)$ and falling $(O)$ temperatures shown in relation to the range of arterial oxygen content (...) observed in all experiments. $\square$, mean of three: 0,0 , single samples. 
of up to $1.5^{\circ} \mathrm{C}$ of the surface temperature of the scrotum of all rams were observed as the scrotum warmed up; these fluctuations were characteristic of those previously ascribed to cooling after the mass discharge of sweat glands (Waites \& Voglmayr, 1962, 1963).

The pattern of respiratory rates of the control rams did not change significantly during the experimental period although the rectal temperatures of both gradually fell by 0.5 and $0.6^{\circ} \mathrm{C}$. One ram ruminated during the later stages of the experiment.

\section{DISCUSSION}

The primary aim of this investigation was to determine some of the immediate metabolic effects of raising the temperature of the testes of conscious rams long enough to cause disruption of spermatogenesis. The most striking effect observed was the increased uptake of oxygen by the testis and epididymis. This was produced mainly by increased removal of oxygen per unit volume of blood passing through the testis, for the volume blood flow was unchanged by the heating applied in three rams although a small increase in blood flow in both testes occurred in the fourth. The oxygen content of the blood in the spermatic veins fell to remarkably low values and the minimum saturation was reached when testicular temperature had risen by 2 to $3^{\circ} \mathrm{C}$ of the 6 to $8^{\circ} \mathrm{C}$ increment imposed. The effect was quickly reversible, for when the testis was cooled, the oxygen content of the spermatic venous blood returned to normal as soon as testicular temperature dropped to about $34^{\circ} \mathrm{C}$. If it can be assumed that blood flow did not change between the two estimates, then the increase in metabolic rate during the first $3^{\circ} \mathrm{C}$ rise $(70 \%)$ is much greater than would have been expected for the whole sheep with a similar increase in body temperature (Graham, Wainman, Blaxter \& Armstrong, 1959).

It has been shown that the oxygen tension of lymph is lower than that of the venous blood and may more closely represent the oxygen tension of the tissue which it drains (Bergofsky, Jacobson \& Fishman, 1962). Thus, the low oxygen contents of the spermatic venous blood recorded here may reflect even lower oxygen tensions in the testicular tissue during heating. Cross \& Silver (1962) reported that testicular oxygen tension in the ram increased after brief local warming, an effect ascribed to vasodilatation in the vicinity of the electrodes. They suggested that this is more likely to be initiated by thermal receptors in the scrotum, because there was probably no rise in the temperature of the testis. Under conditions such that a rise in testicular temperature does occur, a vasodilatation leading to an increased blood flow might be expected. No constant increase in blood flow was observed in the present study but rapid blood flow changes occurring during the warming-up period could not be followed by the technique used. If the venous shunt mechanisms postulated in man (Harrison \& Barclay, 1948) and the arterio-venous anastomoses which exist in sheep testis (Waites, unpublished observations) are functional at elevated temperatures, it might be possible for capillary blood flow in local areas of tissue to differ while the total venous outflow remains unchanged. However, at this laboratory, preliminary measurements of nutrient blood flow in testes at normal temperatures using krypton- 85 give values which agree with 
the current measurements of nutrient and anastomotic flow using tritium. It is clear from the present study that changes in oxygen tension recorded in the testis cannot be assumed to indicate alterations in testicular blood flow unless changes in the metabolic rate of the tissue are excluded.

The important role of glucose in testicular metabolism already demonstrated at normal temperature in anaesthetized rams (Annison, Scott \& Waites, 1963), well-nourished conscious rams (Setchell \& Waites, 1964) and undernourished anaesthetized rams (Setchell, Waites \& Lindner, 1965) was again demonstrated in the present experiments in testes at elevated temperatures. The marked dependence of testicular tissue on glucose for the maintenance of its oxygen uptake in in vitro studies was well recognized (Dickens \& Greville, 1933; Elliott, Greig \& Benoy, 1937), but fragments of rat testes taken 22 to 28 days after being made cryptorchid, when the spermiogenic epithelium was already damaged, did not utilize more glucose than can be accounted for by glycolysis (Tepperman, Tepperman \& Dick, 1949).

More recently the effect of temperature elevation has been examined with testis slices and on isolated testes of rabbits perfused with defibrinated blood to which glucose was added (VanDemark \& Ewing, 1963; Ewing \& VanDemark, 1963a, b). The authors concluded that 'spermatogenic arrest which results from exposure of the testis to elevated temperatures may be caused by reduced levels of substrate in the tissue'. The in vitro studies are open to criticism because the tissue was incubated in a medium (Locke's) which is unbuffered and because the conclusions are based on results from slices incubated in air; under these conditions the centres of the slices would be completely anaerobic (Dixon, 1952). The experiments on slices incubated in oxygen did not support their conclusion, and the oxygen uptake by this tissue was about half that previously reported for rat testis (Dickens \& Greville, 1933; Elliott, Greig \& Benoy, 1937). In the perfusion experiments it was claimed that during heating the glucose uptake by the perfused testis was decreased, whereas in fact it increased in the first $2 \mathrm{hr}$ at $39.5^{\circ} \mathrm{C}$ and fell only in the $3 \mathrm{rd} \mathrm{hr}$ when the fall was roughly proportional to a simultaneous reduction in perfusate flow. Thus, these experiments do not exclude the possibility that the reduction in flow itself brought about a lack of oxygen or of a metabolite other than glucose.

Our experiments do not support the general conclusions of these authors. The heating applied in our experiments was sufficient to cause profound or moderate disruption of spermatogenesis, yet blood flow through the testes was either unchanged or even slightly increased. Indeed, the greatest testicular damage occurred in the ram in which the blood flow through the testes was increased during heating. In all instances, however, the uptake of oxygen was markedly increased by the heating, although $A-v$ oxygen differences quickly returned to normal during the cooling-down period, suggesting that the elevated metabolic rate did not persist after heating. The oxygen content and the concentration of glucose in the arterial blood of the rams were unchanged during the period of elevated testicular temperature so that the supply of oxygen and glucose to the heated testes was not depleted and glucose uptake was slightly increased. The significant fall in the percentage of oxygen which could be accounted for by the oxidation of glucose could be taken to indicate a

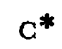


relative reduction in glucose oxidation but similar unaccountable changes were seen in the control rams. Although the oxygen content of the venous blood from heated testes was so low that tissue hypoxia undoubtedly occurred, no increase in the production of lactate was observed as might have been expected from an increased dependence on anaerobic glycolysis.

The respiratory responses of the rams to heating the scrotum were quite characteristic of those demonstrated in rams not previously anaesthetized (Waites, 1961, 1962). The fluctuations in the skin temperatures of the scrotum when it was warming up also closely resembled those which follow a mass discharge of the sweat glands in the scrotum (Waites \& Voglmayr, 1962, 1963). Both thermoregulatory responses occur only if the neural pathways involved are intact and neither occurs in rams anaesthetized with pentobarbitone sodium (Waites, unpublished). This is considered to be good evidence that the central effects of the anaesthetic had gone before the experiment took place. Another encouraging feature was that the libido of all rams and the seminal characteristics of the control rams were unaffected by the period of anaesthesia, surgical manipulation and food deprivation imposed.

Circulatory arrest for about $1 \mathrm{hr}$ leads to complete and irreversible destruction of the germinal epithelium in rat testes (Oettlé \& Harrison, 1952). Since the pathogenesis of testicular damage is similar, whether due to environmental factors or to ischaemia; anoxia or ischaemia were suggested as the cause of all such damage (Harrison, 1956). Blood flow through the testes in the present study was not reduced by the heating applied so that ischaemia was not involved. However, there is some evidence that infertility in the male may follow periods of oxygen lack. For example, about half of the rams taken from sea-level to high altitude in the Andes became temporarily infertile, and the testicular pathology of rabbits, cats, horses and cattle similarly treated resembled that of cryptorchidism (Monge, 1942). Temporary infertility occurred in guinea-pigs breathing 10 vols \% oxygen administered at atmospheric pressure, and this was reversed by doubling the oxygen breathed (Shettles, 1947).

It can be concluded from our experiments that stimulation of metabolism, not matched by an increase in oxygen supply, occurs in the testis of the ram during local heating and this, together with the earlier work, suggests that limitation of the oxygen supply is involved in the mechanism by which local heat causes testicular damage. It can also be concluded that neither pooling of blood due to slowing of flow nor significant vasodilatation are likely to be involved and that, although the amount of glucose reaching the cells may be altered, the amount presented to the testis as a whole is unchanged.

\section{ACKNOWLEDGMENTS}

We wish to thank Messrs J. K. Voglmayr, B. W. Brown and D. Quinlan for their enthusiastic help.

\section{REFERENCES}

Annison, E. F., Scotт, T. W. \& Waites, G. M. H. (1963) The role of glucose and acetate in the oxidative metabolism of the testis and epididymis of the ram. Biochem. 7. 88, 482.

Bergofsky, E. H., Jacobson, J. H. \& Fishman, A. P. (1962) The use of lymph for the measurement of gas tensions in interstitial fluid and tissues. 7. clin. Invest. 41, 1971. 
Gross, B. A. \& Silver, I. A. (1962) Neurovascular control of oxygen tension in the testis and epididymis. 7. Reprod. Fertil. 3, 377.

Dickens, F. \& GReville, G. D. (1933) Metabolism of normal and tumour tissue. VIII. Respiration in fructose and in sugar-free media. Biochem. 7. 27, 832.

Drxon, M. (1952) Manometric methods. Gambridge University Press.

Eleiott, K. A. G., Greig, M. E. \& Benoy, M. P. (1937) The metabolism of lactic and pyruvic acids in normal and tumour tissues. III. Rat liver, brain and testis. Biochem. F. 31, 1003.

Ewing, L. L. \& VANDemark, N. L. (1963a) Factors affecting testicular metabolism and function. II. Effect of temperature elevation in vivo on subsequent metabolic activity of rabbit testicular tissue in vitro. 7. Reprod. Fertil. 6, 9.

Ewing, L. L. \& VanDemark, N. L. (1963b) Factors affecting testicular metabolism and function. III. Effect of in-vitro temperature elevation on tissue slices and perfused testes in the rabbit. $\mathcal{F}$. Reprod. Fertil. 6, 17.

Graham, N. McG., Wainman, F. W., Blaxter, K. L. \& Armstrong, D. G. (1959) Environmental temperature, energy metabolism and heat regulation in sheep. I. Energy metabolism in closely clipped sheep. F. agric. Sci. 52, 13.

Harrison, R. G. (1956) Factors influencing the process of spermatogenesis in the experimental animal. Brit. 7. Urol. 28, 422.

Harrison, R. G. \& Barclay, A. E. (1948) The distribution of the testicular artery (internal spermatic artery) to the human testis. Brit. F. Urol. 20, 57.

Himwich, H. E. \& Nahum, L. H. (1929) The respiratory quotient of the testicle. Amer. F. Physiol. 88, 680.

Huggett, A. Sr. G. \& Nixon, D. A. (1957) The use of glucose oxidase, peroxidase and o-dianisidine in the determination of blood and urinary glucose. Lancet, ii, 368 .

Lundholm, L., Mohme-Lundholm, E. \& Vamos, N. (1963) Lactic acid assay with $\mathrm{L}(+)$ lactic acid dehydrogenase from rabbit muscle. Acta physiol. scand. 58, 243.

Monge, C. (1942) Life in the Andes and chronic mountain sickness. Science, 95, 79.

Moule, G. R. \& Waites, G. M. H. (1963) Seminal degeneration in the ram and its relation to the temperature of the scrotum. F. Reprod. Fertil. 5, 433.

Oettré, A. G. \& Harrison, R. G. (1952) The histological changes produced in the rat testis by temporary and permanent occlusion of the testicular artery. F. Path. Bact. 64, 273.

REID, R. L. (1950) Studies on the carbohydrate metabolism of sheep. I. The range of blood-sugar values under several conditions. Aust. F. agric. Res. 1, 182.

Setchell, B. P. \& Waites, G. M. H. (1964) Blood flow and the uptake of glucose and oxygen in the testis and epididymis of the ram. F. Physiol. 17, 411.

Setched., B. P., Waites, G. M. H. \& Lindner, H. R. (1965) Effect of undernutrition on testicular blood flow, metabolism and testosterone output in the ram. F. Reprod. Fertil. (In press.)

Shetrles, L. B. (1947) Effects of low oxygen tension on fertility in adult male guinea-pigs. Fed. Proc. $6,200$.

Tepperman, J., Tepperman, H. M. \& Dick, H. J. (1949) A study of the metabolism of rat testis in vitro. Endocrinology, 45, 491.

VanDemark, N. L. \& Ewing, L. L. (1963) Factors affecting testicular metabolism and function. I. A simplified perfusion technique for short-term maintenance of rabbit testis. $\mathcal{F}$. Reprod. Fertil. $6,1$.

Waites, G. M. H. (1961) Polypnoea evoked by heating the scrotum of the ram. Nature, Lond. 190, 172.

WAITES, G. M. H. (1962) The effect of heating the scrotum of the ram on respiration and body temperature. Quart. F. exp. Physiol. 47, 314.

Wartes, G. M. H. \& Moule, G. R. (1961) Relation of vascular heat exchange to temperature regulation in the testis of the ram. F. Reprod. Fertil. 2, 213.

Waites, G. M. H. \& Voglmayr, J. K. (1962) Apocrine sweat glands of the scrotum of the ram. Nature, Lond. 196, 965.

Waites, G. M. H. \& Voglmayr, J. K. (1963) The functional activity and control of the apocrine sweat glands of the scrotum of the ram. Aust. 7. agric. Res. 14, 839. 